\title{
Structural aspects of self in personality disorders and the quality of life
}

\author{
Magdalena Błażek \\ Department of Personality Psychology and Forensic Psychology, Institute of Psychology, Faculty of Social Sciences, \\ University of Gdansk, Gdansk, Poland
}

\section{BACKGROUND}

The analyses of personality disorders from the perspective of the structural aspects of Self may allow a better understanding of the psychological functioning of people manifesting a higher level of dysfunctional personality mechanisms. Research on personality disorders suggests that especially the maladaptive features associated with this group of disorders significantly hinder the ability to meet the requirements of the social environment, cause difficulties in coping with stress and thus cause suffering and reduce satisfaction with life.

\section{PARTICIPANTS AND PROCEDURE}

In an effort to examine the relationship between personality disorders and structural aspects of self and quality of life, correlational analyses of one hundred adult participants' responses were conducted. Personality disorders were measured using the Questionnaire of Personality Disorders by Cierpiałkowska (2009). Structural aspects of self were measured with the Self Concept Clarity Questionnaire (SCC) and the Differentiation of Self Inventory (DSI). To assess quality of life, two measures were used: the Satisfaction with Life Scale (SWLS), and the Purpose in Life scale (PIL).

\section{RESULTS}

Personality disorders were negatively related to structural aspects of self, such as clarity of self concept and differentiation of self. They were also negatively correlated with satisfaction with life and the feeling of having a purposeful life.

\section{CONCLUSIONS}

The results indicate that personality disorders lower a person's ability to form a strong and clear self concept, to differentiate between one's feelings and cognitive processes, and to establish autonomous psychological functioning. Apart from that, people manifesting personality disorders have lower quality of life in terms of satisfaction and purpose.

\section{KEY WORDS}

personality disorders; quality of life; self clarity; differentiation of self

Corresponding Author - Magdalena Błażek, Ph.D., Institute of Psychology, Faculty of Social Sciences,

University of Gdansk, 4 Bażyńskiego Str., 80-952 Gdansk, Poland, e-mail: psymb@ug.edu.pl

AUthors' CONTRibution - A: Study design - B: Data collection - C: Statistical analysis - D: Data interpretation .

E: Manuscript preparation · F: Literature search · G: Funds collection

TO CITE THIS ARTICLE - Błażek, M. (2015). Structural aspects of self in personality disorders and the quality of life.

Current Issues in Personality Psychology, 3(1), 42-50.

RECEIVED 05.02.2015 - REVIEWED 13.03.2015 · ACCEPTED 14.03.2015 · PUBLISHED 25.03.2015 


\section{BACKGROUND}

Personality disorders are of interest to both psychology and medicine, and scientific reports mainly concentrate on descriptions of symptoms of these disorders, taking into account the reasons for their occurrence (Cierpiałkowska, 2004; Millon, Grossman, Millon, Meagher, \& Ramnath 2004; Aleksandrowicz, 1997). Personality disorders show such complexity that, according to some authors (Tyrer, 2010; Grabski \& Gierowski, 2012), they are hard to classify. Cierpiałkowska (2013) conducted a broad analysis of the DSM classification system with regards to personality disorders, stressing that the need to refine criteria for individual disorders is the main goal of revising the classifications. Such refinement is an important step towards unification of the understanding and assessment of individual types of disorders. However, the author points out that the transition from the categorical system to a dimensional-categorical system (otherwise referred to as the hybrid system) is very controversial and requires research. Prior classification attempts within the framework of the DSM-IV model allow for their assignment to three main bundles (APA, 1994; Cierpiałkowska, 2008, 2013):

A - personality disorders with weirdness and eccentricity as dominant features, i.e., schizotypal, schizoidal, and paranoiac personalities;

B - personality disorders characterised by dramatization, high emotionality, and a significant disregard for consequences, i.e., borderline, narcissistic, histrionic, and antisocial personalities;

$\mathrm{C}$ - personality disorders characterised by tension and anxiety, i.e., passive-dependent, avoidant, and obsessive-compulsive personalities.

Research on personality disorders suggests that especially the maladaptive and rigid features and low levels of empathy (Kaźmierczak, Pastwa-Wojciechowska, \& Błażek, 2013) associated with this group of disorders significantly hinder the ability to meet the requirements of the social environment and cause difficulties in coping with stressful situations, and thus there is a high probability for them to cause suffering and reduce satisfaction with life (Cierpiałkowska, 2008). Grabowski and Gierowski (2012) suggest that characteristics which impair experiencing the self as a unique individual, with clear borders between oneself and others, as well as those which negatively influence the stability and adequacy of self-assessment and perceived self-worth, are also of great importance. Each personality disorder is associated with a characteristic way of functioning and thinking, as well as defence mechanisms that are specific for a given form of psychopathology (Johnson, 1998). Additionally, individuals with personality disorders show poorly developed conscience, and they do not internalize systems of values, which may be observed through an impaired sense of guilt, or the opposite - exaggerated self-punishment for one's own actions and thoughts (Johnson, 1998).

Personality disorders that are considered to be a consequence of impaired relationships during early stages of development cause a reinforcement of inadequate patterns of attachment (Johnson, 1994; Cierpiałkowska, 2005a, 2005b). Individuals who have experienced pathological relations in their childhood cannot form mature intimate bonds in their adulthood, which results in a chronic impairment in interpersonal functioning. The authors of the synergistic therapy for personality disorders stress the need for a holistic approach in the analysis of the disorders (Millon, Grossman, Millon, Meagher, \& Ramnath, 2004), and they highlight a lack of unequivocal results in research that attempts to describe the roles of pathomechanisms in the development of personality disorders which have a psychosocial and biological character.

According to Cierpiałkowska (2007), personality disorders are recognised on the basis of long-term occurrence of pathological behaviour patterns that are manifested in the cognitive, affective, and interpersonal areas, as well as on the basis of rigidness of these behaviours. The rigidness leads to a decrease in function in the affected individuals, and a lack of adaptation of their behaviour to heterogeneous personal and social contexts. Such behaviour patterns appear before adulthood, and they cause discomfort and a decrease in the quality of life of an affected individual.

\section{CHARACTERISTICS OF PERSONALITY DISORDERS}

According to the characterological developmental theory (Johnson, 1998) the type of characterological problem exhibited by an individual depends on the developmental period in which abnormal development occurred. The character of bonds formed, development of Self in relation to others, and development of Self within a system are critical to the development of a personality. Structural development of an individual takes place in a continuum, and therefore personality disorder may manifest any degree of severity in the continuous spectrum of psychopathology.

According to the aforementioned concept, schizoidal character is one of the characterological types (Johnson, 1998). It is developed as a consequence of experiencing rejection, hate, or an emotional void during childhood. An individual develops a punishing and Self-rejecting attitude as a result of prior experiences. They cannot form intimate relationships with others, have problems with social relations, and exhibit a lifestyle of avoidance and conflict. Very often, people with schizoidal type personalities show 
self-destructive tendencies: they do not accept themselves, appear careless about themselves, have tendencies towards harmful and risky behaviours, and their emotional intelligence is impaired - they do not recognize or understand their own emotions, and they are unable to form mature intimate relationships. Schizotypal disorder is often located on the same axis as schizoidal disorder.

Oral character, or as referred to in DSM-IV, dependent personality, is another characterological problem that is caused by negative experiences at the earliest stage of development - in the period of attachment and bonds (Johnson, 1998; Cierpiałkowska, 2005b). An individual who experiences inadequate care and love from parents, negligence and unmet needs already during childhood remains chronically dependent for the rest of life, but tries to hide it by denying their own needs. Such an individual cannot identify or express their needs, has difficulties in becoming close with others, and this is because of a lack of acceptance for the 'taking' perspective of their own Self. The neglect of their personal needs is compensated for by chronic care of others, fulfilling the other person's needs and taking responsibility for the other person's happiness. The individual gets relief through loving and giving, yet avoids expressing their own needs due to a fear of disappointment and rejection. This is why such individuals often develop symptoms of illness or indisposition which justify getting support from others, lowering the levels of anxiety associated with taking. Individuals that exhibit this type of disorder have a tendency to form relationships based on dependence or mutual dependence.

Among the personality disorders, characterological developmental theory also distinguishes the symbiotic problem, which corresponds to the DSM-IV dependent personality (Johnson, 1998; Cierpiałkowska, 2004). This problem arises through an impaired process of separation and individualisation. The need for separation and autonomy is blocked by parents, and as a result of the experienced frustration, an individual has difficulties in finding their own identity, which causes them to describe themselves not through who they are, but with whom they are. Such individuals do not know what they want, have problems setting life goals and making decisions, as well as defining their own interests and preferences. Their identity is found through others, e.g., relationships with the loved ones. The lack of boundaries between the Self and the social environment may as a consequence lead to a fusion and a 'watering down' of one's own personality. Such individuals often have a sense of guilt associated with the attempts to separate, so they choose being dependent on others over an autonomous development; or they keep a rigid distance, which gives the appearance of independence.

According to the framework of the characterological developmental theory, the narcissistic character also forms as a result of autoexpression frustration. However, in this case the autoexpression is hindered in two ways (Johnson, 1998): on one hand, through parents ridiculing a child's every attempt of self-expression in order to destroy all the grandiose characteristics; and on the other hand, through formulating excessive demands on the child that are associated with an expectation that the child will pursue the projected ideal. An individual with such experiences oscillates between a sense of uselessness and a sense of greatness. A narcissistic problem is therefore mostly linked to the impaired sense of self-worth. Thus, the Self will be characterized by pride, perfectionism, egocentrism, and dependence of the perceived selfworth on achievements. However, when this false image of self breaks down, the individual reacts with a sense of humiliation, shame, and worthlessness.

Histrionic personality is formed when an individual experiences emotional coldness of one parent during childhood, while the other parent is seductive and exploits the natural sexuality of the child (Johnson, 1998). Typically it is the mother who takes the role of a cold parent, and the father forms relations that are tinged with sexuality. Such a pattern is later repeated in adulthood, when an individual plays the role of a 'dear dolly', too immature for their own sexuality. Histrionic individuals usually behave disingenuously, are overly emotional, sometimes even theatrical or dramatising. Their relationships are usually infused with eroticism. Even though an individual will deny their sexuality, they seduce, but are not ready for deep and mature sexual experiences, which is why the histrionic personality is often accompanied by sexual disorders. The sexuality is manifested in isolation from emotionality. Such an individual ascribes extraordinary importance and a superior value to members of the opposite sex, while in fact suppressing a significant hostility, anger, and anxiety.

Obsessive-compulsive personality (also called anankastic personality disorder) is one of the most common disorders. It emerges as a result of an overzealous parental care, especially with regards to the control of sexual impulses and sexual or competitive expression (Johnson, 1998). All the natural and instinctive behaviours are suppressed in such an individual from childhood. The message such a child receives from their parents is that one must strive for permanent control over one's own behaviour and emotions, which leads to rigidness, being overly auto-dominant, and reserved. The effort to control is exhibited through numerous obsessions and compulsions, while rituals and sticking to rules serve to eliminate the need to express the suppressed and unaccepted desires and impulses. Even in their interpersonal relations such individuals remain devoid of emotionality and overly rigid in order to fit into the correct social role. Anxiety is often experienced, and it stems from the constant pursuit of perfection- 
ism and excessive pedantry that is especially visible when the attempts to remain in control over one's behaviour are threatened. Multiple obsessive thoughts and compulsive behaviours help reduce anxiety.

Paranoid personality is characterised by an excessive sensitivity to defeat and rejection, lack of trust, suspiciousness, and a persistent experience of resentment (Cierpiałkowska, 2004). Individuals with this type of disorder often exhibit a sense of guilt, even though on the overt level they express accusations and make demands on others. They appear arrogant and self-confident, but in reality they are shy and full of insecurities. According to Klein (Cierpiałkowska, 2004), such a personality develops on the grounds of early-childhood dissociation between the good and the bad Self, as well as between the good and the bad object. This dissociation may result from experiencing permanent negative appraisal from the mother and an ambivalent attachment to her, which leads to a two-way perceptional orientation. Good representations of Self and objects are held separately from each other, and they undergo introjection, whereas bad ones are projected onto the environment, which fosters an oppressive anxiety associated with the hostility of the external objects. Such individuals suffer social difficulties and lack of acceptance. Other personality disorders, especially those such as schizotypal, schizoid, narcissistic, avoidant, and borderline, may co-occur with paranoid personality.

Avoidant personality, which is also referred to as anxious personality, is characterised by excessive sensitivity to rejection and a need for non-judgemental acceptance that stems from lack of self-confidence (Cierpiałkowska, 2004). Individuals suffering from these disorders are averse to interpersonal contacts and activities that require forming relationships with others. They rarely take risks and engage in new activities. Their self-image is focused on negative beliefs about the self, saturated with judgements of being unattractive and inadequate, and a sense of being inferior. Such an individual will usually behave rigidly and be maladaptive, which leads to impairments in functioning. People with avoidance type disorders usually subjectively perceive themselves as unhappy; they often suffer from somatic problems, as well as showing signs of other types of disorders usually those associated with mood and anxiety. Low sense of self-worth and oversensitivity to rejection cause them to become socially isolated - as a consequence, they receive low amounts of social support in difficult and emergency situations. Parents that are critical and rejecting, frustrating the child's need for acceptance and tolerance, are the cause of avoidance-type behaviours. As a result, a stable sense of security that is needed for one to be able to build mature intimate relationships with others does not develop (Millon et al., 2004).
Borderline personality disorder mainly refers to instability in interpersonal relations, self-image, and emotions, with particularly high impulsivity (Cierpiałkowska, 2004, 2005b). Individuals with borderline personality are very sensitive to rejection, and they experience a chronic fear of separation, which is why they make a lot of effort to avoid it. Such efforts to maintain the closeness of others may take the form of very impulsive behaviours, even as dangerous as self-harm or suicidal attempts. Such people oscillate between idealization of their loved one (partner or caretaker) - associated with the need for exceptional closeness and the requirement that their loved ones share the most intimate details of life with them and devaluation of that person due to the sense that this person does not fulfil their requirements and needs to a sufficient degree. These disorders are often accompanied by an identity disorder characterized by instability of the Self and self-image (Freeman \& Fusco, 2005).

Antisocial personality disorder is characterised by the presence of three mental deficits: anxiety, learning, and interpersonal relations deficits (PastwaWojciechowska, Kaźmierczak, \& Błażek, 2012). Pospiszyl (2000) makes a distinction within the disorder between the impulsive type and calculative type. The author distinguishes: a deficit of fear - an emotional defect characterised by a lack of assimilation of moral reflexes and a lack of empathy; learning deficit - dominant in the impulsive type; and shallow relationships (based on the usefulness of others in fulfilment of one's own goals, ignoring social conventions) - dominant in the calculative type. Cierpiałkowska (2007) suggests that a disregard for other people's values and feelings is particularly clear. Such individuals have a low tolerance for frustration; they are prone to aggressive and risky behaviours, and are unable to experience guilt (Pastwa-Wojciechowska, 2007).

From the perspective of structural aspects of Self, the described personality disorders are characterised by anomalous patterns of describing oneself, the me-world relations, and other people. As a consequence, the regulation of behaviours is impaired, causing a lot of emotional and social problems for the individual. As indicated by Campbell, Assanand, \& Di Paula (2003), a normally developed Self should be characterized by inner cohesion and stability in time, as well as a certainty and clarity of beliefs about oneself that form a construct describing the structure of Self that is described by Campbell as Self-concept clarity (Campbell et al., 1996; Błażek, 2008).

A well-functioning Self is also characterised by a high level of differentiation at the intra-mental and interpersonal levels (Bowen, 1976, 1978, 1991). The first level indicates the ability to separate one's own emotions from thoughts, which is an ability to choose whether to follow the intellect or emotions at a given 
moment. The second interpersonal level is characterised by the ability to remain autonomous, and at the same time experience closeness and intimacy with others (Goldenberg \& Goldenberg, 2006). According to Bowen (1976), the level to which individuals are able to distinguish between their own emotional and intellectual processes determines the level of their differentiation of Self. Thus a differentiated Self means that an individual is able to discriminate between thoughts and feelings, stay faithful to their own values and not automatically give in to emotional signals coming from other people (Goldenberg \& Goldenberg, 2006). Anomalies of functioning in the personal and social spheres, characteristic of personality disorders, reduce psychological wellbeing and make one perceive one's own existence as difficult - both in terms of setting sensible personal goals and building relations. As a consequence, they lower the quality of life associated with the psychological wellbeing of an individual (Diener, Emmons, Larsen, \& Griffin, 1985; Pavot \& Diener, 1993; Suh, Diener, \& Fujita, 1996; Strack, Argyle, \& Schwarz 1991), or the ability to ascribe purpose and meaning to one's own life (Obuchowski, 2000). On the other hand, Raeburn and Rootman (1996) believe that quality of life may be measured by measuring the level of fulfilment of goals set for an individual, while Haidt (2007) points towards the importance of gaining satisfaction from everyday activities and building relations with others.

Thus, two questions emerge: First, are the structural aspects of Self correlated with personality disorders, and if so, how? Second, how do the personality disorders influence the quality of life defined as the sense of purpose and meaning in life in conjunction with general psychological wellbeing?

\section{PARTICIPANTS AND PROCEDURE}

\section{PARTICIPANTS}

Individuals working in the state and public departments took part in the study. In terms of gender and age, participants included 41 men and 59 women ranging in age from 26 to 67 years $(M=36.50$, $S D=11.69$ ). Fifty-one participants had a higher education, and 49 had a secondary education.

\section{PROCEDURE AND MEASURES}

All the subjects received a set of questionnaires and were asked to complete them by assessing the statements therein. The set was composed of: the Personality Disorders Questionnaire (Originally in Polish: Kwestionariusz Zaburzeń Osobowości) $)^{1}$, a Polish adaptation of the Differentiation of Self Inventory (DSI), a Polish adaptation of the Self Concept Clarity Scale (SCC), as well as Polish adaptations of the Purpose in Life (PIL) scale and the Satisfaction with Life Scale (SWLS).

The Personality Disorders Questionnaire developed by Cierpiałkowska (2009) includes 130 items and can be used to diagnose the following personality disorders: paranoid, schizoid, schizotypal, antisocial, borderline, histrionic, narcissistic, anxious, dependent, and anankastic. An experimental version of the tool, made available by its author, was used in this study.

Skowron and Friedlander's Differentiation of Self Inventory (DSI) (1998), adapted to Polish by Błażek in 2011, contains four sub-scales: Emotional Reactivity (which indicates the level to which a given individual reacts to emotional stimuli coming from the outside environment, and measures the extent to which the intellectual and emotional functions are 'fused'), I Position (measures the strength of I, and the level of ability of an individual to remain faithful to their beliefs, values, and goals in response to pressure from the environment), Emotional Cut-off (this scale reveals mechanisms associated with the lack of ability to remain autonomous in relationships), and Fusion with Others (measuring the extent to which an individual is able to deal with separation). The questionnaire also allows for assessing an overall level of differentiation of Self. It measures the capacity for a two-way differentiation of Self: separating the emotions and intellect, and building intimate relationships while remaining autonomous - the dimensions of mature functioning of the Self of an individual, as per Bowen's (1976, 1978, 1991) model.

The Self Concept Clarity Scale (Campbell et al., 1996; 2003), adapted to Polish by Błażek (2008) and Błażek, Besta, and Kaźmierczak (2011), contains 12 items referring to the level of confidence in self-perceptions and the sense of their stability in time. The level of Self Concept Clarity is reflected in the overall score.

The Purpose in Life scale by Crumbaugh and Maholick (1964) and Crumbaugh (1968) allows one to assess the extent to which an individual perceives their life as having purpose and meaning, and is based on the premises of Frankl's existential frustration and noogenic neurosis theory. Part A of the scale, which includes statements related to goals and pursuits, affirmation of life, sense of freedom, self-acceptance, and attitude towards the future and being prepared for death, was used in the current study. The subjects needed to assess their attitudes on a 7-level scale.

The SWLS scale by Diener et al. (1985), adapted to Polish by Juczyński (2001), consists of 5 items referring to one's life history. It provides a general index of psychological wellbeing and satisfaction with life. 
Table 1

Correlations between personality disorders and the dimensions of the differentiation of Self and the overall score on the DSI scale

\begin{tabular}{|c|c|c|c|c|c|}
\hline & $\begin{array}{l}\text { Emotional } \\
\text { reactivity }\end{array}$ & I Position & $\begin{array}{c}\text { Emotional } \\
\text { Cut-off }\end{array}$ & $\begin{array}{c}\text { Fusion with } \\
\text { others }\end{array}$ & $\begin{array}{c}\text { Differentiation } \\
\text { of Self - overall score }\end{array}$ \\
\hline Paranoid & $.21^{*}$ & $-.33^{* *}$ & $.49^{* * *}$ & $.22^{*}$ & $-.49^{* * *}$ \\
\hline Schizoid & .09 & $-.17^{\mathrm{a}}$ & $.62^{* * *}$ & .02 & $-.35^{* * *}$ \\
\hline Schizotypal & $.38^{* * *}$ & $-.32^{* *}$ & $.46^{* * *}$ & $.31^{* *}$ & $-.59^{* * *}$ \\
\hline Antisocial & $.19^{\mathrm{a}}$ & .07 & $.26^{* *}$ & .08 & $-.18^{a}$ \\
\hline Borderline & $.24^{*}$ & $-.19^{a}$ & $.37^{* * *}$ & $.17^{\mathrm{a}}$ & $-.38^{* * *}$ \\
\hline Histrionic & $.46^{* * *}$ & $-.27^{* *}$ & $.32^{* *}$ & $.45^{* * *}$ & $-.58^{* * *}$ \\
\hline Narcissistic & $.32^{* *}$ & $-.19^{a}$ & $.40^{* * *}$ & $.28^{* *}$ & $-.46^{* * *}$ \\
\hline Anxious & $.35^{* * *}$ & $-.48^{* * *}$ & $.57^{* * *}$ & $.24^{*}$ & $-.65^{* * *}$ \\
\hline Dependent & $.44^{* * *}$ & $-.42^{* * *}$ & $.35^{* * *}$ & $.36^{* * *}$ & $-.63^{* * *}$ \\
\hline Anankastic & $.21^{*}$ & -.03 & -.06 & $.27^{* *}$ & $-.21^{*}$ \\
\hline $\begin{array}{l}\text { Personality } \\
\text { disorders }\end{array}$ & $.41^{* * *}$ & $-.34^{* *}$ & $.54^{* * *}$ & $.34^{* *}$ & $-.64^{* * *}$ \\
\hline
\end{tabular}

\section{RESULTS}

The first analysis conducted in this study was concerned with the differences between men and women in presentation of personality disorders. The only significant differences were found within the anankastic personality, which, in the studied group, occurred more frequently among women $(p<.05$, $t(79)=2.20)$. All of the remaining disorders showed no significant differences in occurrence between men and women. However, a tendency was observed for a higher frequency of features of anxious personality among women $(p<.10, t(98)=1.98)$ and anti-social features among men $(p<.10, t(70)=-1.95)$.

\section{PERSONALITY DISORDERS AND THE LEVEL OF DIFFERENTIATION OF SELF}

The analysis of a relationship between personality disorders and differentiation of Self revealed that the higher the level of disorder, the more impaired the functioning of Self in terms of the ability to separate the intellect from the emotional life, and to separate the Self from others. Results are presented in Table 1.

The higher the intensity of a disorder, the lower the differentiation of Self, the higher the emotional reactivity, and the more pronounced the symptoms of emotional cut-off were in the exhibiting individual. Additionally, the analysis of the results allows one to infer that the disorders co-occur with increased Fusion with Others and a lower I Position. Anxious and dependent personalities were found to correlate the most with differentiation of Self $(r=-.65, p<.001$ and $r=-.63, p<.001$ accordingly). The anankastic and antisocial personality disorders were found to be the least strongly correlated with the differentiation of Self (Table 2).

The analysis of correlations revealed that in the case of all of the personality disorders there is an associated low sense of confidence in one's attributes and a reduced sense of their stability in time. Only in the

Table 2

Correlations between personality disorders and Selfconcept clarity

\begin{tabular}{cc}
\hline Personality disorder & Self-concept clarity \\
\hline Paranoid & $-.51^{* * *}$ \\
Schizoid & $-.37^{* * *}$ \\
Schizotypal & $-.44^{* * *}$ \\
Antisocial & -.11 \\
Borderline & $-.39^{* * *}$ \\
Histrionic & $-.36^{* * *}$ \\
Narcissistic & $-.34^{* * *}$ \\
Anxious & $-.64^{* * *}$ \\
Dependent & $-.52^{* * *}$ \\
Anankastic & -.15 \\
Personality disorders & $-.54^{* * *}$ \\
\hline Note &
\end{tabular}


Table 3

Correlations between personality disorders and the sense of purpose in life and satisfaction with life

\begin{tabular}{ccc}
\hline Personality disorder & PIL & SWLS \\
\hline Paranoid & $-.51^{* * *}$ & $-.44^{* * *}$ \\
Schizoid & $-.36^{* * *}$ & $-.27^{* *}$ \\
Schizotypal & $-.40^{* * *}$ & $-.30^{* *}$ \\
Antisocial & -.03 & -.09 \\
Borderline & $-.39^{* * *}$ & $-.38^{* * *}$ \\
Histrionic & $-.41^{* * *}$ & $-.30^{* *}$ \\
Narcissistic & $-.31^{* *}$ & $-.30^{* *}$ \\
Anxious & $-.57^{* * *}$ & $-.49^{* * *}$ \\
Dependent & $-.44^{* * *}$ & $-.39^{* * *}$ \\
Anankastic & .09 & -.01 \\
Personality disorders & $-.47^{* * *}$ & $-.42^{* * *}$ \\
\hline
\end{tabular}

Note. ${ }^{* *} p<.01,{ }^{* * *} p<.001$, PIL - Purpose in Life,

SWLS - Satisfaction with Life Scale

case of the antisocial and anankastic personality did the correlation coefficient not reach significant levels, though the direction of the relationship is the same as in the case of the other disorders, i.e., negative.

As shown in Table 3, many correlations were revealed between personality disorders and the quality of life measured by the PIL and SWLS questionnaires. Only the anankastic and antisocial personalities did not exhibit significant correlations with the investigated variables.

All of the statistically significant indices of correlation are negative, which suggests that there is an inverse correlation between the occurrence of personality disorders and the quality of life. Coefficients of correlation between the different levels of severity of personality disorders were measured altogether as a sum of scores in the Personality Disorder Questionnaire by Cierpiałkowska, and quality of life reached the following values: $r=-.47, p<.001$ for purpose in life; $r=-.42, p<.001$ for satisfaction with life.

\section{DISCUSSION}

In the current study, the relationship between gender and personality disorders was only visible for the anankastic disorder (more frequent among women), anxiety disorders (the frequency was slightly higher among women), and the antisocial disorder (which was more prevalent among men). These results differ only slightly from the data presented by American Psychiatric Association in 1994 (in: Cierpiałkowska, 2007), according to which the prevalence of anankas- tic disorders is higher among men, and anxious personality occurs equally as often among both genders. The differences between the previous data and the current results might arise from cultural differences, the fact that only normally functioning adult individuals took part in the current study, as well as the difficulty in differential diagnosis $-85 \%$ of patients who are diagnosed with one disorder also meet the criteria for another personality disorder (Cierpiałkowska, 2007).

The analysis of correlations between personality disorders and structural aspects of Self suggests that personality disorders are associated with lower levels of differentiation of Self, as well as lower levels of Self-concept clarity (Błażek, 2008). Therefore it can be said that from the perspective of aspects of Self, such as confidence in one's attributes and the sense of their stability in time and in changing situations, as well as the ability to separate the emotional and intellectual control, and taking an autonomous attitude in intimate relationships, individuals with personality disorders do not have a normally developed Self. In-depth analysis of the results suggests that some types of disorders are especially prone to the exacerbation of impaired development of Self. These include: anxious, dependent, and paranoid personalities affecting confidence in one's own attributes, and anxious, dependent, schizotypal, and histrionic personalities affecting the level of differentiation of Self (in both cases, taking into account the sample size, the correlations can be considered strong). The correlation between anxious personality and low differentiation of Self turned out to be the most significant. A lack of beliefs about the self-characteristics that are clear and stable in time is, according to a body of research, correlated with a lower sense of self-efficacy (Campbell, 1990), lower effectiveness of actions (Thomas \& Gedbois, 2007), and decreased psychological wellbeing (Campbell, Assanand, \& Paula, 2003).

The analysis of correlations between personality disorders and quality of life revealed that both the sense of purpose and meaning in life and the overall satisfaction with life are lower among individuals who exhibit features of personality disorders. Decreased sense of purpose and meaning in life co-occurs with anxious and paranoid personality. In line with the aforementioned concepts, personality disorders significantly impair individual and social functioning, as they reinforce the inadequate forms of behaviour and decrease the possibility for adaptation in particularly stressful situations. Tokarski (2006) states that personality disorders are often associated with a subjective sense of suffering and difficulties in fulfilling life objectives, whereas the possibility to fulfil one's potential and goals and the sense of being motivated are an important ingredient for a sense of purpose and meaning in life. Moreover, people with personality disorders exhibit low tolerance for very 
intense emotional states, and due to this they are more likely to experience tension and anxiety.

Fear and anxiety as dominant emotional states and the lack of a sense of control infect all other aspects of life, which, in turn, brings about lower levels of sense of security, decreased self-esteem and sense of self-worth, and decreased sense of self-efficacy, all of which may also lead to a decreased sense of purpose and meaning in life - since the individual has a problem with defining their life goals, is withdrawn, and full of fears and anxiety.

According to Jakubik (2003), the sense of selfworth is usually inadequate in individuals affected with personality disorders - it is either inadequately high or inadequately low. Thus it can take extreme forms ranging from an inferiority complex to grandiosity. The current study also revealed that in personality disorders structural aspects of Self such as clarity and differentiation are also malformed, causing the individual to undertake actions from the perspective of a malfunctioning system of Self. One can therefore infer that the structural aspects of Self (clarity and differentiation) are characterised by low levels in the group of people exhibiting personality disorders of increased severity. This results not only in a decrease in their regulatory functions, but also, as suggested by the measurement of quality of life, lower sense of purpose and meaning in life, and decreased satisfaction with life in general.

\section{ENDNOTE}

1 Results of the Personality Disorders Questionnaire are analysed qualitatively but not quantitatively.

\section{REFERENCES}

Aleksandrowicz, J. (1997). Zaburzenia nerwicowe, zaburzenia osobowości i zachowania dorostych (wedtug ICD-10) - psychopatologia, diagnostyka, leczenie [Neurotic disorders, personality disorders and behaviours of adults (as per ICD-10) psychopathology, diagnosis and treatment] (pp. 121-134). Kraków: Wydawnictwo Uniwersytetu Jagiellońskiego.

American Psychiatric Association. (1994). Diagnostic and statistical manual of mental disorders $\left(4^{\text {th }} \mathrm{ed}\right.$., revised). Washington, DC: American Psychiatric Association.

Błażek, M. (2008). Zróżnicowanie w poziomie dekonstrukcji Ja osób o różnej klarowności samowiedzy w sytuacji wykluczenia społecznego [Differentiation of the level of deconstruction of Self in individuals exhibiting different levels of Self-concept clarity in a situation of social exclusion]. In: M. Plopa, \& M. Błażek (eds.), Wspótczesny czło- wiek w świetle dylematów i wyzwań: perspektywa psychologiczna [Modern individual in the light of dillemas and challenges: a psychological perspective]. Kraków: Impuls.

Błażek, M., Besta, T., \& Kaźmierczak, M. (2011). Skala Klarowności Ja [Self-concept clarity scale]. Niepublikowany manuskrypt [Unpublished manuscript]. Gdansk: Uniwersytet Gdański.

Bowen, G. (1991). The index of similarity: A critical note. Journal of Social Behavior and Personality, 6, 175-178.

Bowen, M. (1976). Theory in the practice of psychotherapy. In: P. J. Guerin, Jr. (ed.), Family therapy: Theory and practice (pp. 42-90). New York: Gamer Press.

Bowen, M. (1978). Family therapy in clinical practice. New York: Aronson.

Campbell, J. D. (1990). Self-esteem and clarity of the self-concept. Journal of Personality and Social Psychology, 59, 538.

Campbell, J. D., Trapnell, P. D., Heine, S. J., Katz, I. M., Lavallee, L. F., \& Lehman, D. R. (1996). Self-concept clarity: Measurement, personality correlates, and cultural boundaries. Journal of Personality and Social Psychology, 70, 141.

Campbell, J. D., Assanand, S., \& Paula, A. D. (2003). The structure of the self-concept and its relation to psychological adjustment. Journal of Personality, 71, 115-140.

Cierpiałkowska, L. (2004). Zaburzenia osobowości w modelach medycznych i psychologicznych [Personality disorders in medical and psychological models]. In: Cierpiałkowska, L. (ed.), Psychologia zaburzeń osobowości. Wybrane zagadnienia [The psychology of personality disorders. Selected problems]. Poznan: Wydawnictwo Naukowe Uniwersytetu im. A. Mickiewicza.

Cierpiałkowska, L. (2005a). Koncepcje interakcyjne i systemowe oraz ich znaczenie w psychologii klinicznej [Interaction and systemic concepts and their meaning in cilinical psychology]. In: H. Sęk (ed.), Psychologia kliniczna [Clinical psychology] (Vol. 1) (pp. 132-152). Warsaw: Wydawnictwo Naukowe PWN.

Cierpiałkowska, L. (2005b). Psychologia zaburzeń osobowości i zaburzeń lękowych [The psychology of personality disorders and anxiety disorders]. In: H. Sęk (ed.), Psychologia kliniczna [Clinical psychology] (Vol. 2) (pp. 47-74). Warsaw: Wydawnictwo Naukowe PWN.

Cierpiałkowska, L. (2007). Psychopatolgia [Psychopathology]. Warsaw: Wydawnictwo Naukowe "Scholar".

Cierpiałkowska, L. (2008). Psychologia zaburzeń osobowości: wybrane zagadnienia [The psychology of personality disorders. Selected problems]. Poznań: Wydawnictwo Naukowe Uniwersytetu im. Adama Mickiewicza. 
Cierpiałkowska, L. (2009). Questionnaire of Personality Disorders (unpublished experimental version). Poznan: Univeristy of Adam Mickiewicz.

Cierpiałkowska, L. (2013). Personality disorders in DSM classification. Current Issues in Personality Psychology, 1, 1-10.

Crumbaugh, J. C. (1968). Cross-validation of Purpose in Life Test based on Frankl's concepts. Journal of Individual Psychology, 24, 74-81.

Crumbaugh, J. C., \& Maholick, L. T. (1964). An experimental study in existentialism: The psychometric approach to Frankl's concept of noogenic neurosis. Journal of Clinical Psychology, 20, 589-596.

Diener, E. D., Emmons, R. A., Larsen, R. J., \& Griffin, S. (1985). The satisfaction with life scale. Journal of Personality Assessment, 49, 71-75.

Freeman, A., \& Fusco, G. M.(2005). Borderlinetraits. In: N. Kazantzis, F. P. Deane, K. R. Ronan, \& L. L'Abate (eds.), Using homework assignments in cognitive behavior therapy (pp. 268-290). Great Britain: Routledge Taylor \& Francis Group.

Goldenberg, I., \& Goldenberg, H. (2006). Terapia rodzin [Family Therapy]. Kraków: Wydawnictwo Uniwersytetu Jagiellońskiego.

Grabski, B., \& Gierowski, J. K. (2012). Zaburzenia osobowości - różne spojrzenia i próby ich integracji [Personality disorders - different outlooks and an attempt to integrate them]. Psychiatria Polska, $5,829-844$.

Haidt, J. (2007). Szczęście: od mądrości starożytnych po koncepcje wspótczesne [The Happiness Hypothesis: finding modern truth in acient wisdom]. Gdańsk: Gdańskie Wydawnictwo Psychologiczne.

Jakubik, A. (2003). Zaburzenia osobowości [Personality disorders]. Warsaw: Wydawnictwo Lekarskie PZWL.

Johnson, S. M. (1994). Przemiana charakterologiczna cud ciężkiej pracy [Characterological transformation. The hard work miracle]. Warsaw: Jacek Santorski \& Co Agencja Wydawnicza.

Johnson, S. M. (1998). Style charakteru [Character styles]. Poznań: Zysk i S-ka.

Juczyński, Z. (2001). Narzędzia pomiaru w promocji i psychologii zdrowia [Measurements for health psychology and health promotion]. Warsaw: PTP.

Kaźmierczak, M., Pastwa-Wojciechowska, B., \& Błażek, M. (2013). A multidimensional model of empathy and the occurrence of personality disorders and stress in social settings. Acta Neuropsychologica, 2, 113-125.

Millon, T., Grossman, S., Millon, C., Meagher, S., \& Ramnath, R. (2004). Personality disorders in modern life. New York: John Wiley \& Sons, Inc.

Obuchowski, K. (2000). Galaktyka potrzeb - psychologia dążeń ludzkich [A galaxy pf needs - psychology of human pursuits]. Poznań: Zysk i S-ka.

Pastwa-Wojciechowska, B. (2007). Psychopatia a antyspołeczne i dyssocjalne zaburzenia osobowości [Psychopathy and antisocial and dissocial perso- nality disorders]. In: J. M. Stanik (ed.), Psychospoteczne uwarunkowania i mechanizmy kryminogenezy a zachowania paraprzestępcze i przestępcze [Psychosocial determinants and mechanisms of criminogenesis, and paracriminal and criminal behaviours] (pp. 208-220). Warsaw: Wydawnictwo Komandor.

Pastwa-Wojciechowska, B., Kaźmierczak, M., \& Błażek, M. (2012). Self-esteem and styles of coping with stress versus strategies of planning in people with psychopathic personality disorders. Medical Science Monitor, 2, 119-124.

Pavot, W., \& Diener, E. (1993). Review of the satisfaction with life scale. Psychological Assessment, 5, 164.

Pospiszyl, K. (2000). Psychopatia [Psychopathy]. Warsaw: Wydawnictwo Żak.

Raeburn, J. M., \& Rootman, I. (1996). Quality of life and health promotion. In: R. Renwick, I. Brown, M. Nagler (eds.), Quality of Life in Health Promotion and Rehabilitation: Conceptual approaches, issues, and applications (pp. 75-88). Thousand Oaks, CA: Sage 1996.

Skowron, E., \& Friedlander, M. (1998). The Differentiation of Self Inventory: Development and Initial Validation. Journal of Counselling Psychology, 45, 235-246.

Strack, F., Argyle, M., \& Schwarz, N. (1991). Subjective well-being: an interdisciplinary perspective. Oxford: Pergamon Press.

Suh, E., Diener, E., \& Fujita, F. (1996). Events and subjective well-being: only recent events matter. Journal of Personality and Social Psychology, 70, 1091.

Thomas, C. R., \& Gadbois, S. A. (2007). Academic self-handicapping: The role of self-concept clarity and students' learning strategies. British Journal of Educational Psychology, 77, 101-119.

Tokarski, S. (2006). Osoba, osobowość, zaburzenia osobowości: wybrane materiaty z konferencji na temat Psychologia i psychoterapia wobec zaburzeń osobowości, symptomatologia i diagnostyka, przyczyny i skutki, profilaktyka i terapia zaburzeń osobowości zorganizowanej przez Stowarzyszenie Psychologów Chrześcijańskich. Warszawa-Konstancin, 15-17 kwietnia 2005 r. [An individual, personality, personality disorders: selected materials from the 'Psychology and psychotherapy of personality disorders, symptomatology and diagnosis, causes and consequences, prophylaxis and therapy of personality disorders' conference organisted by the Society of Christian Psychologists Warsaw-Konstancin, 15-17 April 2005]. Płock: Płocki Instytut Wydawniczy.

Tyrer, P. (2010). Personality structure as an organizing construct. Journal of Personality Disorders, 24, 14-24. 